\title{
Comment on "A Pragmatic Approach to Resolving Technological Unfairness: The Case of Nike's Vaporfly and Alphafly Running Footwear"
}

\author{
Víctor Rodrigo-Carranza ${ }^{1}$, Fernando González-Mohíno ${ }^{1,2^{*}}$ (D, Jordan Santos-Concejero ${ }^{3}$ and \\ José María González-Ravé ${ }^{1}$
}

\section{To the Editor,}

We have read with great interest the manuscript recently published in your journal on the technological unfairness of the use of Nike Vaporfly and Alphafly running footwear models [1]. In the section "Do the Nike Vaporfly/Alphafly Shoes Provide an Unfair Advantage?", the author claimed that the performance progression in long-distance, such as the marathon and the half-marathon, has not changed and that 'the shoes' introduction has not obtained any greater change than the reasons attributed to any former record being broken".

\section{Background}

Joyner et al. [2] evaluated the progression of world record performances in marathon since the late 1920s. On average, a 20s reduction per year since 1960 was found, but since 1980, the average reduction was lower (10s) per year, showing a stagnation in progression. Since the release of this type of footwear (2017), all men's and women's world records in long-distance road running events have been broken by athletes wearing new technological footwear [3]. Moreover, it has been suggested that

This comment refers to the article available online at https://doi.org/10.1186/ s40798-020-00250-1.

A reply to this letter is available online at https://doi.org/10.1186/s40798-02100379-7.

*Correspondence: Fernando.GMayoralas@uclm.es

1 Sport Training Lab, University of Castilla-La Mancha, Toledo, Spain

Full list of author information is available at the end of the article "recent improvements in these events are unlikely physiological but rather technological, iffor no other reason that such a step-wise improvement in physiological attributes underpinning performance is unlikely". A recent metaanalysis [4] confirms that using shoes with increased longitudinal bending stiffness and a curved plate (such as the Vaporfly shoes) implies a technological improvement of $\sim 3.45 \%$ in running economy (RE). These RE changes provide $\mathrm{a} \sim 2 \%$ improvement in marathon performance [5]. Therefore, the relation between RE improvement and performance is clear.

\section{Performance Enhancements in the New Technological Footwear Era}

However, recent retrospective studies [6, 7] analysing the use of Vaporfly shoes in long-distance running events have confirmed improvements on the performance previously found in laboratory conditions. Bermon et al. [6] reported a decrease in elite athlete's season best times in $10-\mathrm{km}$, half-marathon and marathon events from 2017 in the top 20 and top 100 best times per year. While this study assessed the footwear worn by runners only for the top 20 from 2016 to 2019, a recent study from our research group [8] identified more than the $90 \%$ of footwear worn in these three events for the top 100 best times per year from 2015 to 2019. For example, in the years before the 2017 (when this type of footwear was released), the year-on-year improvement of marathon performances between 2015 and 2017 was only of 
$0.14-0.21 \%$ for the top 100 best times, while from 2017 onwards the performance improved between 0.75 and $1.50 \%$ compared to 2015 and 2016. In addition, there was a strong correlation between number of runners using this footwear per year and marathon performance improvements $(r=0.96)$.

Moreover, another study from our research group (under review) evaluated the impact of the Vaporfly shoes on the best Marathon times in history, where 23 of the 50 (46\%) best times in history (accessed 20 November 2020) have been achieved with Vaporflys, and 21 of them being achieved since 2018 (42\%). In addition, from the best performances under 2:03:00, every performance except the one by Dennis Kimetto (former World Record, Berlin Marathon, 28 September 2014) has been achieved with Vaporfly shoes.

\section{Conclusion}

We conclude that the new technological footwear implies a clear impact in long-distance running performance, and probably an unfair advantage due to the greater improvements they provide when compared to the years prior of the technological revolution.

Acknowledgements

Not applicable.

\section{Authors' Contributions}

VRC and FGM conceived and designed research. VRC, FGM, JMGR and JSC wrote the manuscript. All authors read and approved the final manuscript.

\section{Funding}

No sources of funding were used in the preparation of this article.

\section{Availability of Data and Materials}

Not applicable.

\section{Declarations}

Ethics Approval and Consent to Participate

Not applicable. The individual informed consent was not necessary.

\section{Consent for Publication}

Not applicable.

\section{Competing Interests}

Victor Rodrigo Carranza, Fernando González Mohíno, Jordan Santos Concejero and José María González Ravé declare that they no competing interests.

\section{Author details}

${ }^{1}$ Sport Training Lab, University of Castilla-La Mancha, Toledo, Spain. ${ }^{2}$ Facultad de Ciencias de la Vida y de la Naturaleza, Universidad Nebrija, Madrid, Spain. ${ }^{3}$ Department of Physical Education and Sport, University of the Basque Country UPV/EHU, Vitoria-Gasteiz, Spain.

Received: 9 August 2021 Accepted: 4 November 2021

Published online: 17 December 2021
References

1. Dyer B. A pragmatic approach to resolving technological unfairness: the case of Nike's Vaporfly and Alphafly running footwear. Sport Med Open. 2020:6:1-10.

2. Joyner MJ, Ruiz JR, Lucia A. The two-hour marathon: who and when ? J Appl Physiol. 2011;110:275-7.

3. Muniz B, Shaun P, Konstantinos S, Fergus A, Bosch A, Pitsiladis Y. Recent improvements in marathon run times are likely technological, not physiological. Sport Med. 2021;51:371-8.

4. Rodrigo-Carranza V, González-Mohíno F, Santos-Concejero J, GonzálezRavé JM. The effects of footwear midsole longitudinal bending stiffness on running economy and ground contact biomechanics: a systematic review and meta-analysis. Eur J Sport Sci. 2021.

5. Kipp S, Kram R, Hoogkamer W. Extrapolating metabolic savings in running: Implications for performance predictions. Front Physiol. 2019:10:1-8.

6. Bermon S, Garrandes F, Szabo A, Berkovics I, Adami PE. Effect of advanced shoe technology on the evolution of road race times in male and female elite runners. Front Sport Act Living. 2021;3:1-6.

7. Rodrigo-Carranza V, González-Mohino F, Casado A, Santos-Concejero J, Galán-Rioja MA, Hermosilla F, et al. Impact of Vaporfly shoes model in critical speed in elite runners. Book of Abstract ECSS. 2021.

8. Rodrigo-Carranza V, González-Mohíno F, Santos del Cerro J, Santos-Concejero J, González-Ravé JM. Influence of advanced shoe technology on the top 100 annual performances in men's marathon from 2015 to 2019. Sci Rep. 2021. https://doi.org/10.1038/s41598-021-01807-0. (In press).

\section{Publisher's Note}

Springer Nature remains neutral with regard to jurisdictional claims in published maps and institutional affiliations.

\section{Submit your manuscript to a SpringerOpen ${ }^{\odot}$ journal and benefit from:}

- Convenient online submission

- Rigorous peer review

- Open access: articles freely available online

- High visibility within the field

- Retaining the copyright to your article

Submit your next manuscript at springeropen.com 